FARMING FOR HEALTH 
Wageningen UR Frontis Series

VOLUME 13

\section{Series editor:}

R.J. Bogers

Frontis - Wageningen International Nucleus for Strategic Expertise, Wageningen University and Research Centre, Wageningen, The Netherlands

Online version at http://www.wur.nl/frontis 


\title{
FARMING FOR HEALTH
}

\author{
Green-Care Farming Across Europe \\ and the United States of America
}

Edited by

\section{JAN HASSINK}

Research International, Wageningen University and Research Centre, Wageningen, The Netherlands

and

MAJKEN VAN DIJK

Animal Sciences Group, Wageningen University and Research Centre, Wageningen, The Netherlands

\section{算 Springer}


A C.I.P. Catalogue record for this book is available from the Library of Congress.

ISBN-10 1-4020-4540-9 (HB)

ISBN-13 978-1-4020-4540-0 (HB)

ISBN-10 1-4020-4541-7 (PB)

ISBN-13 978-1-4020-4541-7 (PB)

Published by Springer,

P.O. Box 17, 3300 AA Dordrecht, The Netherlands.

www.springer.com

Logo: Ronald Nederhof

Printed on acid-free paper

All Rights Reserved

(C) 2006 Springer

No part of this work may be reproduced, stored in a retrieval system, or transmitted in any form or by any means, electronic, mechanical, photocopying, microfilming, recording or otherwise, without written permission from the Publisher, with the exception of any material supplied specifically for the purpose of being entered and executed on a computer system, for exclusive use by the purchaser of the work.

Printed in the Netherlands. 


\section{CONTENTS}

Thematic studies

1. Theoretical models for research and program development in agriculture and health care: avoiding random acts of research Paula Diane Relf (USA)

2. Contributions of natural elements and areas in residential environments to human health and well-being Sjerp de Vries (The Netherlands)

3. Effects of interactions between humans and domesticated animals

Eddie A.M. Bokkers (The Netherlands)

4. People-plant interaction: the physiological, psychological and sociological effects of plants on people Marjolein Elings (The Netherlands)

5. Social services as supplementary on-farm activity for mentally disabled people Katja Vadnal and Katarina Košmelj (Slovenia)

6. The lay beliefs about Farming for Health

Elsa Fjeldavli (Norway)

7. The contribution of care farms to landscapes of the future: a challenge of multifunctional agriculture

Thomas van Elsen (Germany), Amelie Günther (Germany) and Bas Pedroli (The Netherlands)

8. Long-term care in Europe: an introduction

Piet F. Driest (The Netherlands) 
9. Green care in Norway: farms as a resource for the educational, health and social sector Lisbeth Haugan, Ragnhild Nyland, Elsa Fjeldavli, Toril Meistad and Bjarne O. Braastad (Norway)

10. 'Nature and Health' in Sweden

Karin Abramsson and Carina Tenngart (Sweden)

11. Farming for Health in Finland

Ulla Partanen, Taina Lilja, Sirpa Kurppa And Katriina Soini (Finland)

12. Care farms and care gardens: horticulture as therapy in the UK

Joe Sempik and Jo Aldridge (United Kingdom)

13. Farming for Health in The Netherlands

Marjolein Elings and Jan Hassink (The Netherlands)

14. Farming for Health - the situation in Flanders

Katrien Goris and Hilde Weckhuysen (Belgium)

15. Farming for Health: aspects from Germany

Konrad Neuberger, Ingrid Stephan, Robert Hermanowski, Albrecht Flake, Franz-Joseph Post, Thomas van Elsen (Germany)

16. INTEGRATION: youth welfare and sustainable development in Switzerland

Peter Frey, Susanne Frutig, Urs Kaltenrieder And Jörg Wetzel (Switzerland)

17. Farming for Health in Austria: farms, horticultural therapy, animal-assisted therapy

Georg Wiesinger, Fritz Neuhauser and Maria Putz (Austria)

18. Farming for Health in Slovenia

Katja Vadnal (Slovenia)

19. Farming and social-care combinations in Poland

Ewa Pawelczyk (Poland) 
20. Farming for Health in Italy

Francesco di Iacovo, Saverio Senni and Jeanette de Kneght (Italy)

21. Agriculture and health care: the care of plants and animals for therapy and rehabilitation in the United States Paula Diane Relf (USA)

\section{Conclusions}

22. Farming for Health across Europe: comparison between countries, and recommendations for a research and policy agenda

Jan Hassink and Majken van Dijk (The Netherlands) 


\section{PREFACE}

The utilization of agricultural farms as a basis for promoting human mental and physical health and social well-being is a relatively recent development. The health sector and social services currently appear to need alternatives to traditional medical treatment, therapy, rehabilitation, and work training. On farms, the animals, the plants, the garden, the forest and the landscape are used in recreational or workrelated activities, for psychiatric patients, people with learning disabilities, people with a drug history, problem youth, burnout and elderly people and social-service clients. If not pure therapy, such activities may have therapeutic value according to extensive experience. The numbers of such multifunctional farms offering Green Care services are increasing rapidly in many countries. The positive experiences seem to be similar in different countries: working on the farm contributes to self-esteem, social skills, rehabilitation, inclusion, responsibility, physical health and sense of purpose (Lenhard et al. 1997; Ketelaars et al. 2002; Vadnal 2003). Important recognized qualities of Green Care farms are the space, quietness, useful work, diverse activities, caring activities, working with plants and animals and the protective and caring environment of the farmer's family and the social community.

The therapeutic use of plants and farm animals in projects involving horticulture and animal-assisted therapy and activity is well known in several countries. Most of these projects were associated with hospitals and health institutions. Nowadays an increasing number of projects are adopted by community gardens, city farms, allotment gardens and farms. Social farming appears as an evolving, dynamic scenario, which is gaining increasing attention from multiple stakeholders. In most countries social farming is not an organized system, but rather a patchwork-like reality developed from bottom-up actions.

There is much practical experience in utilization of farms, farm animals, plants, gardens and the landscape for rehabilitation and therapy for different target groups. So far, however, the exchange of knowledge and experiences between different countries is limited. Participants from twelve European countries and the US, involved in social farming or Green Care, horticultural therapy and animal-related therapies, initiated a Community of Practice 'Farming for Health' in 2004. The term 'Farming for Health' comprises a wide spectrum of different kinds of social agriculture in different countries, including social farming or Green Care and the specific use of plants, landscapes, gardens and farm animals in therapy or in a recreative setting in order to improve well-being or to reach pre-defined goals. The motive to start this Community of Practice was the observation that Farming for Health is growing across Europe and that different regions and countries can learn from each other. Participants from the different countries are highly motivated to exchange information, to develop a research agenda and a common conceptual framework in order to professionalize this new field. The participants realized that in order to professionalize this new field it is important to get a clear picture of the 
state of the art concerning Farming for Health in the different countries. This book is the result of their dedication.

The first part contains scientific papers dealing with different aspects of Farming for Health. The second part describes the situation in different countries. The last chapter presents the main differences and similarities between different countries and the recommendations for a research and policy agenda that were formulated during the second meeting of the Community of Practice in March 2005.

\section{ACKNOWLEDGEMENTS}

The editors thank the participants and authors from the different countries for their contributions, and their co-organizers ${ }^{1}$ of the first and second meeting of the Community of Practice 'Farming for Health', both in The Netherlands (Vorden, April 2004, and Wageningen, March 2005). This book is the first product of the Community of Practice.

The editors also thank the sponsors of the meetings: The European Science Foundation (ESF), Triodosfonds, Ionastichting and Frontis - Wageningen International Nucleus for Strategic Expertise.

Thanks are also due to the Committee of Recommendation: H. Wijffels (Chairman of the Social-Economic Council of the Netherlands), W. Visscher (Council of Europe), C. Ross-van Dorp (Minister of Public Health, Welfare and Sport of The Netherlands), J. Troost (Chronic-patient and Handicapped Council of The Netherlands) and M. Glöckler, Medical section of Goetheanum.

Finally special thanks to Rob Bogers and Petra van Boetzelaar of Frontis for their continuous support in the publication of this book and the preparation of the workshops.

The editors,

Jan Hassink and Majken van Dijk

\section{NOTES}

${ }^{1}$ Piet Driest (Netherlands Institute for Care and Welfare), Joke van der Veer and Ina Kattebroek (National Support Centre Agriculture and Care), Marjolein Elings, Gerard Kolkman and Yvon Schuler (Centre of Expertise Agriculture, Nature and Health, Wageningen University and Research Centre: Plant Research International, Alterra and Animal Sciences Group, respectively), Henk Poppenk and Truida de Raaf (Stichting OMSLAG), Bas Pedroli (Petrarca) and Wiebe Cool (Centre of Expertise Agriculture and Care Dronten)

\section{REFERENCES}

Ketelaars, D., Van Erp, N. and Hassink, J., 2002. Landbouw en zorg in beeld: blik op heden en toekomst. Plant Research International, Wageningen. Rapport / Plant Research International no. 50. [http:// library.wur.nl/wasp/bestanden/LUWPUBRD_00318774_A502_001.pdf]

Lenhard, L., Mövius, R. and Dabbert, S., 1997. Struktur und Organisationsformen von Therapieund Betreuungseinrichtungen in der Landwirtschaft: eine explorative Studie. Berichte ber Landwirtschaft, 75, 459-485.

Vadnal, K., 2003. Povpraševanje po socialnih storitvah kot dopolnilni dejavnosti na kmetiji. In: Kavčič S., Erjavec, E. and Kuhar, A. eds. Slovensko kmetijstvo in Evropska unija. 1. izd. Društvo Agrarnih Ekonomistov Slovenije (DAES), Ljubljana, 259-272. 